\title{
The Evaluation of Methylated Septin 9 in Blood Plasma and Tissue Biopsies for the Early Detection for Asymptomatic Colon Cancer
}

\author{
Ahmed Ageeb Kassid ${ }^{1}$, Omar F. Abdul-Rasheed ${ }^{2 *}$, Nawal Mehdi AlKhalidy ${ }^{3}$ \\ ${ }^{1}$ Department of Biochemical Sciences, Faculty of Pharmacy, Al-Rafidain University College, Baghdad, Iraq; ${ }^{2}$ Department of \\ Chemistry and Biochemistry, College of Medicine, Al-Nahrain University, Baghdad, Iraq; ${ }^{3}$ Department of Gastroenterology, GIT \\ and Hepatology Teaching Hospital, Medical City, Baghdad, Iraq
}

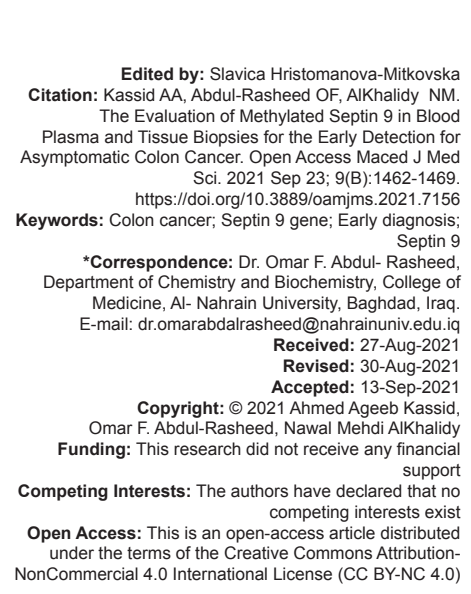

\section{Abstract}

AIM: The purpose of this study was to assess the utility of the Septin 9 (SEPT9) genetic marker in the early detection of colon cancer (CC) patients.

METHODS: A case-control study was conducted on forty newly diagnosed CC patients. The study was done between March 2019 and January 2020, patients from the Gastroenterology and Liver Education Hospital, Al-imamain Al-Kadhimain Medical City, and Baghdad Teaching Hospital were recruited. CC patients' mean age \pm standard deviation was $54.4 \pm 10.79$ years while the age \pm standard deviation of the mean of the control group was $55.1 \pm 8.54$ years. For septin9 tissue methylation of the controls was done on the non-malignant tissues of the same patients.

RESULTS: This study concluded that the percentage of Septin 9 (SEPT9) in the tissue of patients with CC was the highest value, which is more significant than that of the serum of CC patients. Both of these groups were significantly higher than the percentage of SEPT9 methylation of control tissue and serum. Non-significant differences were obtained in the levels of Carcinoembryonic antigen and CA19-9 between CC patients and controls.

CONCLUSION: The percentage of SEPTIN9 methylation in serum and tissue patients with a family history for CC was significantly higher than CC patients without a family history.

\section{Introduction}

Colorectal cancer (CRC) has become the $3^{\text {rd }}$ most common malignancy in men and the second in women [1]. It accounts for approximately $10 \%$ of the global cancer burden [2]. Survival of CRC patients is significantly associated with the staging of the disease at diagnosis [2]. The five-year survival rate for CRC patients diagnosed in the early stage is more than $90 \%$, while for those diagnosed in the late stage is approximately $7 \%$ [3].

Therefore, it is urgent to reduce CRC mortality and morbidity rates by improving screening [1]. The main molecular mechanisms causing CRC include chromosome instability (CIN), microsatellite instability (MSI), and CpG island methylator phenotype (CIMP) [4].

DNA methylation is an important epigenetic modification, and $\mathrm{CpG}$ island is the main site of DNA methylation and is closely related to the occurrence and development of tumors [5]. Aberrant methylation as a regulator of gene expression has been demonstrated previously in colorectal cancer [6].
Aberrantly methylated genes are attractive candidate markers for cancer detection [7]. As methylation occurs in distinct genomic areas, methylated markers in tumor tissues and body fluids are likely targets for the early detection of cancers [7].

Septins are a family of GTP-binding proteins that play important roles in cytokinesis, the cytoskeleton, and cell cycle control [8]. As a star member of the Septin gene family, Septin9 (SEPT9) is located at chromosome 17q25.3 and demonstrates oncogenic and tumor-suppressive impacts on human cancers [9]. The previous research has linked methylated SEPT9 (mSEPT9) to cancer through transcriptional silencing due to aberrant hypermethylation of the $\mathrm{CpG}$ island in the SEPT9 promoter region [10].

The previous independent case-control studies using clinically confirmed colorectal cancer cases and colonoscopy verified healthy asymptomatic controls suggested that detecting mSEPT9 in plasma may indicate the presence of CRC [11], [12], [13].

The present study was aimed to investigate the diagnostic value of plasma and tissue mSEPT9 for colon cancer (CC). 


\section{Methods}

\section{Ethics}

The study protocol was submitted to the institutional review board of the College of Medicine, Al-Nahrain University, and approved before the start of the study. All subjects provided informed consent before blood collection.

\section{Subjects and study design}

A case-control study was conducted on forty individuals who were diagnosed with CC at an early stage. There were forty participants in the control group. The controls for tissue SEPTIN9 methylation, on the other hand, were performed on non-malignant tissue from the same patients. Patients were recruited from March 2019 to January 2020 at Gastroenterology and Hepatology Teaching Hospital, Al- Imamain Al- Khadimain Medical City, and Baghdad Teaching Hospital. In Baghdad, Iraq, the study's practical part was carried out at Al-Nahrain University's Department of Chemistry and Biochemistry, College of Medicine. The patients were included for this study if they had suspicious CC (newly diagnosed) recorded by clinical examination and colonoscopy. The control group includes people who have no evidence of the disease. The criteria for exclusion were: Systemic infections, digestive diseases, malabsorptive diseases, acute medical conditions, and other malignant diseases.

\section{Blood samples collection and preparation}

Ten milliliters of peripheral blood samples were collected in a $10 \mathrm{~mL}$ tube containing the $\mathrm{K}_{2}$ EDTA anticoagulant from patients and controls that had fasted for $8 \mathrm{~h}$.

Plasma samples (4.5 mL) without apparent hemolysis, chylemia, high bilirubin or visible particles or pellets were collected on centrifugation and stored under $-20^{\circ} \mathrm{C}$ within 3 weeks from the sample collection date. Blood samples of CC patients who had taken colonoscopy examinations were collected before surgery.

\section{Carcinoembryonic antigen (CEA) measurement [14]}

The Sandwich-ELISA concept is used in this ELISA kit. The antibody unique to Human CEA has been pre-coated on the micro ELISA plate used in this kit. Standards or samples are mixed with the same antibody in the micro ELISA plate wells. The optical density (OD) is measured spectrophotometrically at a wavelength of $450 \mathrm{~nm}$. The OD value is proportional to the concentration of Human CEA present in the study. The concentration of Human CEA in the samples was determined by comparing the OD of the samples to the standard curve.

\section{CA19-9 measurement [15]}

This ELISA kit employs the Sandwich-ELISA approach. A pre-coated micro ELISA plate with an antibody specific for Human CA19-9 is included in this kit. In the micro ELISA plate wells, standards or samples are combined with the same antibody. By comparing the OD of the samples to the standard curve, the concentrations of Human CA19-9 in the samples were estimated

\section{DNA extraction}

DNA Extraction from blood samples [16]

The ReliaPrepTM Blood gDNA Miniprep System extracts pure, intact DNA from mammalian blood quickly and straightforwardly. The samples are processed using a binding column in a microcentrifuge tube. Each purification may process up to $200 \mu \mathrm{l}$ of blood. The genomic DNA is of good quality and may be utilized in common applications including agarose gel analysis, restriction enzyme digestion, and PCR analysis. The ReliaPrepTM Blood gDNA Miniprep System employs a straightforward four-step process:

1. Getting the DNA out of the starting material by effectively disrupting or homogenizing it

2. Used the ReliaPrepTM Binding Column to attach DNA

3. Used a wash solution to remove impurities

4. The elution of purified DNA. The purification protocol contains no ethanol, thereby avoiding downstream issues caused by ethanol carryover.

Genomic DNA was isolated from blood samples according to the protocol

ReliaPrep $^{\mathrm{TM}}$ Blood gDNA Miniprep System, Promega as the following steps:

1. In a rotisserie shaker at room temperature, thoroughly mixed the blood sample for $15 \mathrm{~min}$

2. Twenty $\mu$ l of Proteinase K (PK) Solution was dispensed into each $1.5 \mathrm{ml}$ microcentrifuge tube, followed by $200 \mu$ l of blood, which was briefly mixed

3. To lyse the cells, $200 \mu$ l of Cell Lysis Buffer was added to the tube and vortexed for $10 \mathrm{~s}$

4. All of the mixtures were incubated for $30 \mathrm{~min}$ in a water bath at $56^{\circ} \mathrm{C}$

5. A ReliaPrepTM Binding Column was inserted into an empty selection tube while the blood sample was incubated 
6. After incubation, the tube was removed from the water bath and $250 \mu$ l of Binding buffer was added, which was vortexed for $10 \mathrm{~s}$

7. The tube contents were transferred to the ReliaPrep $^{\mathrm{TM}}$ Binding Column and centrifuged at $12,000 \mathrm{rpm}$ for $3 \mathrm{~min}$

8. The collection tube containing flow-through was removed and discarded

9. The binding column is placed into a fresh collection tube

10. Five hundred microliters of column wash solution was poured to the column and centrifuged for $3 \mathrm{~min}$ at the maximum speed; the flow-through was discarded; this procedure was repeated 3 times

11. After the washing step, the column was placed in a clean $1.5 \mathrm{ml}$ microcentrifuge tube, and $100 \mu$ of nuclease-free water was added to the column

12. After $5 \mathrm{~min}$, the $1.5 \mathrm{ml}$ tube with column centrifuge for $5 \mathrm{~min}$ at $5000 \mathrm{rpm}$

13. After centrifuge, the ReliaPrep ${ }^{\mathrm{TM}}$ binding column discarded and eluate saved.

\section{DNA Extraction from tissue samples}

1. Harvested cells were moved to a $1.5 \mathrm{ml}$ microcentrifuge tube. Until harvesting, adherent cells were trypsinized

2. The cells were centrifuged at 13,000-16,000 $\times$ $\mathrm{g}$ for $10 \mathrm{~s}$ to pellet the cells

3. Supernatant removed, leaving behind the cell pellet plus $10-50 \mu$ l of residual liquid

4. Cells were washed by adding $200 \mu \mathrm{l}$ of PBS and vortexed vigorously to resuspend cells. Centrifuges as in Step 1.b, and removed the PBS

5. $\quad 600 \mu \mathrm{l}$ of nuclei lysis solution added and pipetted to lyse the cells. The mixture was pipetted until no visible cell clumps remain

6. Three microliters of RNase solution was added to the nuclear lysate, and the sample was mixed by inverting the tube 2-5 times. The mixture was incubated for $15-30 \mathrm{~min}$ at $37^{\circ} \mathrm{C}$ before being allowed to cool to room temperature for 5 min before proceeding

7. $200 \mu \mathrm{l}$ of protein precipitation solution was added to the room temperature sample and vortexed forcefully at high speed for $20 \mathrm{~s}$. The sample was cooled for $5 \mathrm{~min}$ on ice

8. At 13,000-16,000 g, the sample was centrifuged for $4 \mathrm{~min}$, the precipitated protein clumped together to form a compact white pellet

9. The supernatant containing the DNA (leaving the protein pellet behind) was carefully removed and transferred to a clean $1.5 \mathrm{ml}$ microcentrifuge tube containing $600 \mu$ of room temperature isopropanol
10. Inversion was used to gently mix the solution until the white thread-like strands of DNA formed a visible mass

11. They were centrifuged for $1 \mathrm{~min}$ at $13,000-16,000 \times g$ at room temperature. The supernatant was carefully decanted. The DNA becomes visible as a small white pellet

12. Six hundred microliters at room temperature of $70 \%$ ethanol was added and gently inverting the tube several times to wash the DNA, the tube was centrifuged for $1 \mathrm{~min}$ at $13,000-16,000 \mathrm{~g}$. The ethanol was carefully aspirated using either a drawn Pasteur pipette or a sequencing pipette tip. The DNA pellet is very loose at this point, and care must be used to avoid aspirating the pellet into the pipette

13. The tube was inverted on clean absorbent paper and air-dried the pellet for 10-15 min

14. DNA was rehydrated by adding one hundred microliters of the DNA rehydration solution by incubating at $65^{\circ} \mathrm{C}$ for $1 \mathrm{~h}$. The solution was gently mixed by gently tapping the tube. Alternatively, the DNA can be rehydrated by incubating the solution at room temperature or $4^{\circ} \mathrm{C}$ overnight

15. The resultant DNA is stored at $2-8^{\circ} \mathrm{C}$

\section{Primer}

\section{Primer preparation}

The primer used in this study was listed in Table 1.

Table 1: Primer characteristics

\begin{tabular}{|c|c|c|c|}
\hline Primer name & Sequence & $\begin{array}{l}\text { Annealing } \\
\text { Temp }\left({ }^{\circ} \mathrm{C}\right)\end{array}$ & $\begin{array}{l}\text { Product } \\
\text { size (bp) }\end{array}$ \\
\hline SEPT9_M-F & 5'-TTAAGTTTAAGGAAATCGTAGTATCG-3`' & 60 & 263 \\
\hline SEPT9_M-R & 5'-AACCACCGAATCTACCTACGAA-3' & & \\
\hline SEPT9_U-F & 5'-AATTTTTAA GTTTAAGGA AATTGTAGTATT-3` & & 254 \\
\hline SEPT9_U-R & 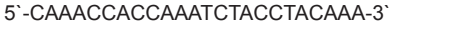 & & \\
\hline myoD-F & $5^{\circ}$-TGATTAATTTAGATTGGGTTTAGAGAAGGA-3` & & 162 \\
\hline myoD-R & $5^{\circ}$-ССААСТССАААТССССТСТСТАТ- $3^{\prime}$ & & \\
\hline
\end{tabular}

The preparation of primer was conducted as shown in Table 2.

Table 2: The preparation of primers

\begin{tabular}{lll}
\hline Primer name & Vol. of nuclease-free water $(\mu \mathrm{l})$ & Concentration $(\mathrm{pmol} / \mu \mathrm{l})$ \\
\hline SEPT9_M-F & 290 & 100 \\
SEPT9_M-R & 300 & 100 \\
SEPT9_U-F & 290 & 100 \\
SEPT9_U-R & 300 & 100 \\
myoD-F & 290 & 100 \\
myoD-R & 300 & 100 \\
\hline SEPT9: Septin 9. & \multicolumn{2}{c}{ The } \\
\multicolumn{2}{c}{ Tacrogen Company } & Supplied these
\end{tabular}
primers in a lyophilized form. To obtain a working primer solution of $10 \mathrm{pmol} / \mu \mathrm{l}, 10 \mu \mathrm{l}$ of primer stock solution (stored at freezer $-20^{\circ} \mathrm{C}$ ) was mixed with $90 \mu \mathrm{l}$ of nuclease-free water. As a stock solution, lyophilized primers were dissolved in nuclease-free water to a final concentration of $100 \mathrm{pmol} / \mu \mathrm{l}$. 


\section{Primer optimization programs}

The DNA template was amplified with the same primer pair, (Forward) (Reverse), at annealing temperatures of $55,58,60,63$, and $65^{\circ} \mathrm{C}$ to determine the optimum annealing temperature of primer. PCR amplifications were performed with $20 \mu \mathrm{l}$ volumes containing $10 \mu \mathrm{l}$ Go Taq Green Master Mix (2x); $1 \mu \mathrm{l}$ for each primer (10 pmol); $6 \mu$ nuclease-free water; and $2 \mu \mathrm{l}$ of template DNA as listed below for both SEPTIN-9 gene. The primer optimizing program is listed in Table 3.

Table 3: Primer optimization programs

\begin{tabular}{lc}
\hline Reagent & Volume \\
\hline Go Taq Green Mix (2X) & $10 \mu \mathrm{l}$ \\
Forward Primer & $1 \mu \mathrm{l}$ \\
Reverse Primer & $1 \mu \mathrm{l}$ \\
Nuclease free water & $6 \mu \mathrm{l}$ \\
Template DNA & $2 \mu \mathrm{l}$ \\
Total & $20 \mu \mathrm{l}$ \\
\hline
\end{tabular}

Reaction setup and thermal cycling protocol

Gene: SEPT9_M, SEPT9_U, and myoD

\begin{tabular}{lllll}
\hline No. of reaction & 160 & rxn & The annealing temperature of primers & 60 \\
\hline Reaction Volume/run & 10 & $\mathrm{Ml}$ & No. of primers & 3 \\
Safety margin & 5 & $\%$ & No. of PCR Cycles & 40 \\
\hline
\end{tabular}

The PCR reaction mixtures were mixed according to the master mix's manufacturer's instructions (Promega). All appending was done in a laminar flow cabinet using frozen cold blocks and ice as needed. Table 4 shows the components of PCR operation (4).

Table 4: The components of PCR work

\begin{tabular}{|c|c|c|c|c|c|c|}
\hline \multirow[t]{3}{*}{ Master mix components } & \multirow[t]{3}{*}{ Stock } & \multirow[t]{3}{*}{ Unit } & \multirow[t]{3}{*}{ Final } & \multirow[t]{3}{*}{ Unit } & \multicolumn{2}{|l|}{ Volume } \\
\hline & & & & & 1 & 120 samples \\
\hline & & & & & \multicolumn{2}{|l|}{ Sample } \\
\hline Master Mix & 2 & $\mathrm{X}$ & 1 & $\mathrm{X}$ & 5 & 600 \\
\hline $\begin{array}{l}\text { Forward } \\
\text { Primer }\end{array}$ & 10 & $\mu \mathrm{M}$ & 1 & $\mu \mathrm{M}$ & 0.5 & 60 \\
\hline $\begin{array}{l}\text { Reverse } \\
\text { Primer }\end{array}$ & 10 & $\mu \mathrm{M}$ & 1 & $\mu \mathrm{M}$ & 0.5 & 60 \\
\hline $\begin{array}{l}\text { Nuclease Free } \\
\text { Water }\end{array}$ & & & & & 3 & 360 \\
\hline DNA & & $\mathrm{ng} / \mu \mathrm{l}$ & $\mathrm{ng} / \mu \mathrm{l}$ & & 1 & \\
\hline Total volume & & & & & 10 & \\
\hline Aliquot per & $9 \mu \mathrm{l}$ & ster $\mathrm{n}$ & per tu & and & $d \mu \mathrm{l}$ of te & late \\
\hline
\end{tabular}

single rxn

The real time PCR program was listed in Table 5.

\section{Statistical analysis}

The study's data were saved in a Microsoft Excel spreadsheet. The data were entered into a spreadsheet and processed on a device using the SPSS software 20 and Microsoft Excel program (2010). Categorical variables were represented as numbers and analyzed by cross-tabulation to assess the occurrence and percentage of each variable within the studied groups. The numeric variables were expressed as mean $\pm S D$, and all statistical comparisons were represented using an independent t-test and ANOVA test with $p \leq 0.05$ being found statistically significant. The correlation was done between all parameters using Pearson correlation test [17], eta $(\eta)$ test between numerical and categorical variables (values ranged from 0 to 0.5 considered as weak correlation whereas values above 0.5 were considered as strong correlation) and Chi-square to test the relationships among categorical variables, all statistical analyses were carried out using SPSS program.

The accuracy of the analyzed markers was assessed using a Receiver Operating Characteristic (ROC) study as a comprehensive method. When comparing various biomarkers, the area under the curve (AUC) is a valuable method. AUC close to 1 implies an excellent diagnostic and predictive marker, while AUC $=0.5$ has no diagnostic significance. AUC close to 1 is always accompanied by satisfactory values of specificity and sensitivity of the biomarker [18].

\section{Results}

\section{General characteristics of the study groups}

In this study, some anthropometric characteristics of the studied groups summarized in Table 4 and (Figure 1) were assessed through analyzing questionnaire answered via a direct interview with all subjects. Table 6 shows non-significant differences in age and body mass index (BMI) between all studied groups.

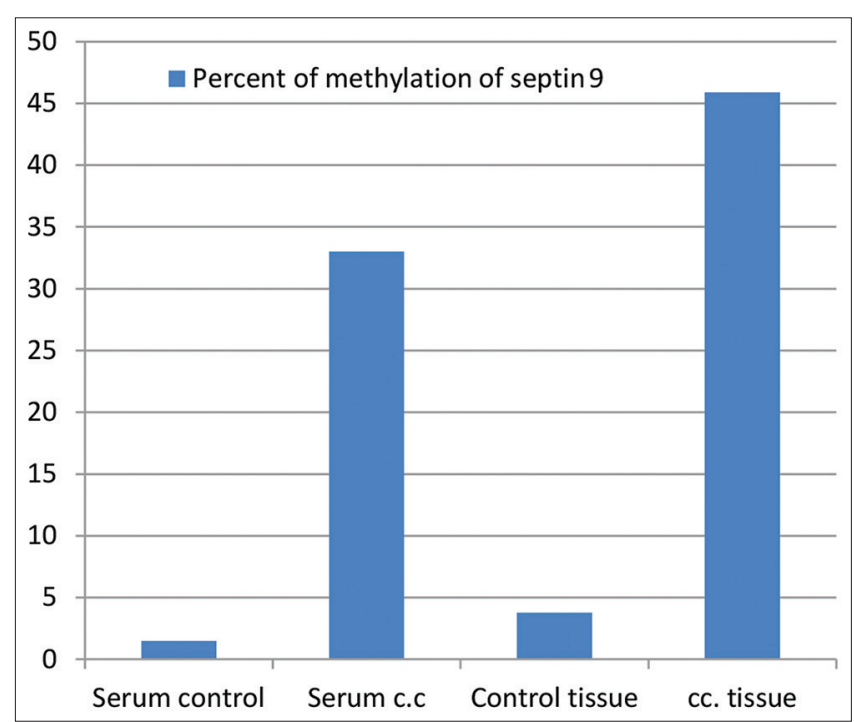

Figure 1: Percentage of Septin 9 methylation in all studied groups

\section{Percentage of SEPT9 methylation in} serum and tissue of patients with CC against the percentage of SEPT9 methylation in tissue and serum of control group

According to results illustrated in Table 3 and Figure 1, the percentage of SEPT9 in the tissue of patients with CC was the highest value $(45.88 \pm 24.69)$ which is significantly higher $(p<0.001)$ than those in the serum 
Table 5: Real-time PCR program

\begin{tabular}{llll}
\hline Steps & ${ }^{\circ} \mathrm{C}$ & $\mathrm{m}: \mathrm{s}$ & Cycle \\
\hline Initial & 95 & $05: 00$ & 1 \\
Denaturation & & & \\
Denaturation & 95 & $00: 15$ & 40 \\
Annealing & 60 & $00: 30$ acquiring & \\
Extension & 72 & $00: 60$ & \\
\hline
\end{tabular}

Table 6: Anthropometric characteristics of the CC in comparison with controls

\begin{tabular}{llll}
\hline Parameter & Control & CC & $\mathrm{P}^{\mathrm{b}}$ \\
\hline Number & 40 & 40 & \\
Age $($ year) & $55.1 \pm 8.54$ & $54.4 \pm 10.79$ & 0.731 \\
BMI $\left(\mathrm{kg} / \mathrm{m}^{2}\right)$ & $26.25 \pm 2.28$ & $25.45 \pm 3.59$ & 0.238 \\
\hline
\end{tabular}

of CC patients $(29.03 \pm 16.09)$ and both of these groups were higher significantly $(p<0.001)$ than the percentage of SEPT9 methylation of control tissue $(3.79 \pm 4.49)$ and serum $(1.196 \pm 0.82)$ and the only exception was the non-significant difference between the two control groups (serum and tissue). Moreover, the ANOVA test revealed that there was a highly significant difference $(p<0.001)$ among all studied groups, as demonstrated in Table 7.

Table 7: The percent of Septin9 methylation in all studied groups

\begin{tabular}{|c|c|c|c|c|c|c|c|c|}
\hline Group & Mean \pm SD & $\mathrm{P}^{\mathrm{a}}$ & $\mathrm{P}^{6}$ & $\mathrm{P}^{\mathrm{c}}$ & $P^{d}$ & $\mathrm{P}^{\mathrm{e}}$ & $P^{f}$ & $\mathrm{P}^{9}$ \\
\hline \multicolumn{9}{|l|}{ SEPT9 } \\
\hline \multicolumn{9}{|l|}{ Methylation (\%) } \\
\hline $\begin{array}{l}\text { Control } \\
\text { (serum) } n=40\end{array}$ & $1.196 \pm 0.82$ & $<0.001$ & $<0.001$ & 0.864 & $<0.001$ & $<0.001$ & $<0.001$ & $<0.001$ \\
\hline CC (serum) & $29.03 \pm 16.09$ & & & & & & & \\
\hline $\begin{array}{l}\mathrm{n}=40 \\
\mathrm{CC} \text { (tissue) }\end{array}$ & $45.88 \pm 24.69$ & & & & & & & \\
\hline $\begin{array}{l}n=40 \\
\text { Control } \\
\text { (tissue) } n=40\end{array}$ & $3.79 \pm 4.49$ & & & & & & & \\
\hline $\begin{array}{l}P^{a} \text { : Value between th } \\
\text { percentage of methy } \\
\text { methylation in contro } \\
\text { tissue and CRC ser } \\
\mathrm{P}^{f} \text { value between the } \\
\text { via ANOVA test. SEP }\end{array}$ & $\begin{array}{l}\text { ne percentage of } m \\
\text { ylation in colon can } \\
\text { ol tissue and contro } \\
\text { um. } P^{\mathrm{e}} \text { value betwe } \\
\text { e percentage of me } \\
\text { PT9: Septin } 9, \text { CC: }\end{array}$ & $\begin{array}{l}\text { ethylation } \\
\text { cer tissue } \\
\text { ol serum. F } \\
\text { en the per } \\
\text { thylation i } \\
\text { Colon can }\end{array}$ & $\begin{array}{l}\text { in CC ser } \\
\text { and contr } \\
{ }^{d} \text { value be } \\
\text { rcentage o } \\
\text { in control ti } \\
\text { ccer. }\end{array}$ & $\begin{array}{l}\text { fum and } \\
\text { ol serum } \\
\text { etween th } \\
\text { of methyl } \\
\text { issue an }\end{array}$ & $\begin{array}{l}\text { control ser } \\
P^{c} \text { value } \\
\text { e percent } \\
\text { ation in co } \\
d \text { CC tissu }\end{array}$ & $\begin{array}{l}\text { rum. } P^{b}: \text { va } \\
\text { between th } \\
\text { tage of me } \\
\text { ontrol tissue } \\
\text { e. } P^{g} \text { value }\end{array}$ & $\begin{array}{l}\text { alue betwe } \\
\text { the percent } \\
\text { ethylation in } \\
\text { le and CC } \\
\text { le among a }\end{array}$ & $\begin{array}{l}\text { een the } \\
\text { tage of } \\
\text { in CC } \\
\text { serum. } \\
\text { all groups }\end{array}$ \\
\hline
\end{tabular}

\section{The percentage of SEPT9 methylation in} serum and tissue of patients with a family history of CC compared to those with no family history

Data postulated in Table 8 obviate that the percentages of SEPTIN9 methylation in serum and tissue of patients with a family history of CC were significantly higher than those of CC patients without a family history. In contrast, the control samples showed a non-significant difference in the percentage of SEPIT9 methylation between these two subgroups.

Table 8: The percentage of SEPTIN9 methylation in serum and tissue of CC patients and control tissue in patients with a family history of CC compared to those with no family history

\begin{tabular}{llc}
\hline Group & Mean \pm SD & $\mathrm{P}^{\mathrm{a}}$ \\
\hline \% of SEPTIN9 methylation in serum of CC patients & & \\
$\quad$ Patients with a family history $\mathrm{n}=12$ & $38.37 \pm 14.75$ & 0.014 \\
$\quad$ Patients without family history $\mathrm{n}=28$ & $25.03 \pm 15.16$ & \\
\%of SEPTIN9 methylation in tissue of CC patients & & \\
$\quad$ Patients with family history $\mathrm{n}=12$ & $67.57 \pm 23.21$ & $<0.001$ \\
$\quad$ Patients without a family history $\mathrm{n}=28$ & $36.59 \pm 19.05$ & \\
\% of SEPTIN9 methylation in controls tissue & & \\
$\quad$ Patients with a family history $\mathrm{n}=12$ & $5.29 \pm 5.07$ & 0.17 \\
$\quad$ Patients without family history $\mathrm{n}=28$ & $3.15 \pm 4.15$ & \\
\hline CC: Colon cancer, $\mathrm{P}^{\mathrm{a}}$ value between the percentage of methylation in serum and tissue in CC and control \\
with and without family history.
\end{tabular}

\section{ROC analysis}

$R O C$ analysis for the percentage of SEPTIN9 methylation in serum and tissue

Results illustrated in Figure 2 revealed that the assessment of the percentage of SRPTIN9 methylation in serum could be considered as a reliable test as it demonstrated a high (AUC $=0.945$ ) with excellent sensitivity and specificity ( $90 \%$ for each) which is nearly comparable to those of percentage of SRPTIN9 methylation tissues $(\mathrm{AUC}=0.965$, sensitivity $=90 \%$, and specificity $=100$ ).

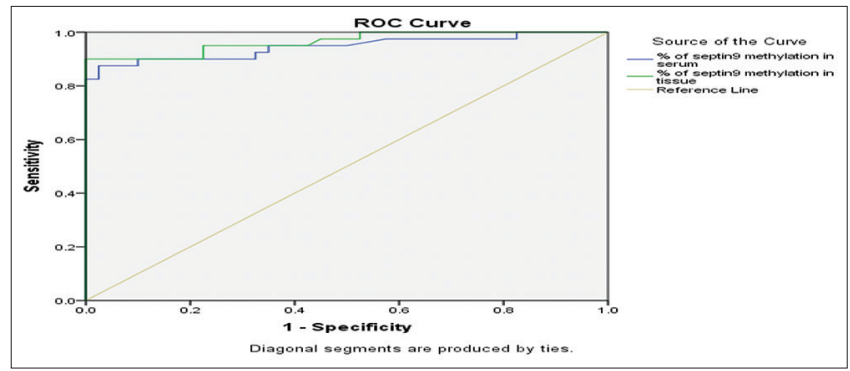

Figure 2: Receiver operating characteristic curve of the percentage of SEPTIN9 methylation in serum and tissue

\section{Discussion}

$\mathrm{CC}$ is the third most common cancer in men and the second most common cancer in women, with approximately 1.4 million cases and 693,900 deaths/ year. As with other cancers, accurate diagnosis is critical for successful treatment, and early detection is critical in lowering CC patient mortality. Despite rapid advancements in CC screening, such as colonoscopy, fecal occult blood testing (FOBT), immunochemical FOBT, and fecal DNA examination, tumor detection has not improved to a satisfactory level. Furthermore, overcomplicated testing, high costs, and a lack of compliance are reducing the applicability and sensitivity of testing [19]. Several studies have been carried out to identify non-invasive markers for the diagnosis and prognosis of $\mathrm{CC}$, ranging from classical tumor markers such as CEA and carbohydrate antigen 19-9 (CA 19-9) to more recent markers [20], [21], [22], [23]. Several experiments were carried out in the ROC curve of Septin9 in serum and tissue. We obtained Septin9 percentage values in serum as a reliable test because they demonstrated a high $(A \cup C=0.945)$ with excellent sensitivity and privacy (90\% each), which are nearly identical to the percentage of methyl tissue Septin9 shown in Table 8 and Figures 1 and 2.

\section{Levels of CEA and Carbohydrate antigen} 19-9 (CA 19-9) in CC patients and controls

Since the levels of CEA and CA 19-9 seen in this analysis were not substantially higher in patients 
with early-stage $\mathrm{CC}$ than controls, these markers cannot be recommended as $\mathrm{CC}$ screening measures. The poor sensitivity of serum CEA and CA 19-9 for detecting $\mathrm{CC}$ is the main reason. The sensitivities of CEA, CA 19-9, and the combination of CEA and CA 19-9 for CC were found to be very poor in this analysis, with findings similar to those found in the previous studies [24]. Furthermore, CEA, CA 19-9, and the mixture of CEA and CA 19-9 had low AUCs for CC. These findings reinforce the notion that CEA and CA 19-9 should not be suggested as instruments for $\mathrm{CC}$ early detection tests, which is in line with previous research through Xie et al., who discovered that CEA and $\mathrm{Ca}$ 19-9 have low success in detecting $\mathrm{CC}$, indicating that they should not be recommended for CC screening [25]. Although serum CEA and CA 19-9 are not recommended as CC screening measures, they are widely used as part of a health screening program [24].

Data obtained in the present work revealed that CEA levels might be affected by cigarette smoking. It showed higher CEA levels in smokers compared to non-smoker patients that may interfere with the diagnostic value. The effect of cigarette smoking was discussed previously in several researches [26], [27]. A more recent study conducted on CRC patients showed that the prognostic value of CEA might be affected by cigarette smoking as it causes an increase in serum CEA levels independently of the disease status [28]

Furthermore, when comparing patients with a CC family history to patients without a CC family history, all CA19-9 and CEA levels showed a non-significant decrease, suggesting that these levels in CC patients are independent of their family history, particularly because all CC patients included in this study were diagnosed early and CA19-9 and CEA levels did not begin to rise [28]. The association between CEA and CA19-9 was non-significant in all observed participants, including $\mathrm{CC}$ patients, confirming the poor diagnostic significance of these markers in the early stages of $\mathrm{CRC}$. This revealed that their slight elevation is not parallel.

Given that all of the patients had been diagnosed with CRC at an early stage, there were no substantial associations between era, BMI, and cigarette smoking habit, and these two tumor markers. The poor diagnostic importance of CEA and CA 19-9 in patients early diagnosed with $\mathrm{CC}$ is also shown through $\mathrm{ROC}$ study findings, which reveal a low AUC, sensitivity, and specificity that are nearly comparable to the previous literature data [29], [30]. The combination of CEA and CA19-9 provides a higher sensitivity of up to $80 \%$, suggesting the likelihood of utilizing this combination for early CRC detection. The reality that serum CEA levels may be elevated in other malignancies as well as mild disorders (i.e., cirrhosis and ulcerative colitis), and even smoking, which tends to almost double the CEA serum concentration in stable participants, contributes to CEA's poor sensitivity and specificity [15], [31].
Percentage SEPT9 in tissue and serum of CRC patients and controls

SEPT9 is a cell cycle-related protein indispensable for coordinating myosin motor proteins during cytokinesis. SEPT9 stabilizes the polymer, promotes the aggregation of subunits, and plays a key role in the final separation of daughter cells during cell division. Therefore, when the SEPT9 gene is abnormally expressed or deleted, cell division may be seriously affected. The SEPT9 gene is abnormally expressed in many malignant tumors. SEPT9 is a tumor suppressor gene, and it is methylated in a variety of tumors. Hyper methylation is related to gene expression silencing and genomic instability; reduced expression of tumor suppressor genes and DNA repair genes; and effects on normal cellular functions, such as apoptosis, DNA repair, and cell cycle regulation. It was reported that hypermethylation of the $\mathrm{CpG}$ island in the promoter region of the SEPT9 gene could inhibit its expression, abrogating its tumor suppressor functions and ultimately results in malignant tumor formation [31].

Results obtained in the current research agree with the previous findings in that the percentage of SEPT9 methylation was elevated significantly in the tissues of early diagnosed CRC patients compared to non-cancerous tissues obtained from the same patients. The remarkable finding in the present work is the high percentage of SEPT9 methylation in serum of CRC patients compared to those in the serum of controls. These results may provide a promising non-invasive tool for early diagnosis of CRC, given that several researchers considered that the measurement of methylation percentage of SEPT9 is a promising blood/ plasma-based assay for early CRC detection [10].

This study concluded that the percentage of SEPT9 in the tissue of patients with CC was the highest value, which is more significant than that of the serum of CC patients. Both of these groups were significantly higher than the percentage of SEPT9 methylation of control tissue and serum.

Non-significant differences were obtained in the levels of CEA and CA19-9 between CC patients and controls.

The percentage of SEPTIN9 methylation in serum and tissue patients with a family history for $\mathrm{CC}$ was significantly higher than $\mathrm{CC}$ patients without a family history.

\section{References}

1. Wu D, Zhou G, Jin P, Zhu J, Li S, Wu Q, et al. Detection of colorectal cancer using a simplified SEPT9 gene methylation assay is a reliable method for opportunistic screening. J Mol Diagn. 2016;18:535-45. https://doi.org/10.1016/j. jmoldx.2016.02.005 


\section{PMid:27133379}

2. Fu B, Yan P, Zhang S, Lu Y, Pan L, Tang W, et al. Cell-free circulating methylated SEPT9 for noninvasive diagnosis and monitoring of colorectal cancer. Dis Markers. 2018;2018:6437104. https://doi.org/10.1155/2018/6437104 PMid:29849824

3. Bresalier RS, Kopetz S, Brenner DE. Blood-based tests for colorectal cancer screening: Do they threaten the survival of the FIT test? Dig Dis Sci. 2015;60(3):664-71. https://doi. org/10.1007/s10620-015-3575-2

PMid:25680874

4. Simons CC, Hughes LA, Smits KM, Khalid-de Bakker CA, de Bruïne AP, Carvalho B, et al. A novel classification of colorectal tumors based on microsatellite instability, the $C p G$ island methylator phenotype and chromosomal instability: Implications for prognosis. Ann Oncol. 2013;24(8):2048-56. https://doi. org/10.1093/annonc/mdt076 PMid:23532114

5. Sun J, Fei F, Zhang M, Li Y, Zhang X, Zhu S, Zhang S. The role of mSEPT9 in screening, diagnosis, and recurrence monitoring of colorectal cancer. BMC Cancer. 2019;19(1):450. https://doi. org/10.1186/s12885-019-5663-8

PMid:31088406

6. Ebert MP, Mooney SH, Tonnes-Priddy L, Lograsso J, Hoffmann J, Chen J, et al. Hypermethylation of the TPEF/HPP1 gene in primary and metastatic colorectal cancers. Neoplasia. 2005;7(8):771-8. https://doi.org/10.1593/neo.05235

PMid:16207479

7. Church TR, Wandell M, Lofton-Day C, Mongin SJ, Burger M, Payne SR, et al. Prospective evaluation of methylated SEPT9 in plasma for detection of asymptomatic colorectal cancer. Gut. 2014;63(2):317-25. https://doi.org/10.1136/gutjnl-2012-304149 PMid:23408352

8. Shen N, Wang T, Li D, Zhu Y, Xie H, Lu Y. Hypermethylation of the SEPT9 gene suggests significantly poor prognosis in cancer patients: A systematic review and meta-analysis.Front Genet. 2019;10:887. https://doi.org/10.3389/fgene.2019.00887 PMid:31608117

9. Verdier-Pinard $P$, Salaun D, Bouguenina $H$, Shimada $S$, Pophillat M, Audebert S, et al. Septin 9-i2 is downregulated in tumors, impairs cancer cell migration and alters subnuclear actin filaments. Sci Rep. 2017;7:44976. https://doi.org/10.1038/ srep44976

PMid:28338090

10. Wang Y, Chen PM, Liu RB. Advance in plasma SEPT9 gene methylation assay for colorectal cancer early detection. World J Gastrointest Oncol. 2018;10(1):15-22. https://doi.org/10.4251/ wjgo.v10.i1.15

PMid:29375744

11. Lofton-Day C, Model F, Devos T, Tetzner R, Distler J, Schuster M et al. DNA methylation biomarkers for blood-based colorectal cancer screening. Clin Chem. 2008;54(2):414-23. https://doi. org/10.1373/clinchem.2007.095992

PMid:18089654

12. Grützmann R, Molnar B, Pilarsky C, Habermann JK, Schlag PM, Saeger HD, et al. Sensitive detection of colorectal cancer in peripheral blood by septin 9 DNA methylation assay. PLoS One. 2008;3(11):e3759. https://doi.org/10.1371/journal. pone.0003759

PMid:19018278

13. deVos T, Tetzner R, Model F, Weiss G, Schuster M, Distler J, et al. Circulating methylated SEPT9 DNA in plasma is a biomarker for colorectal cancer. Clin Chem. 2009;55:1337-46. https://doi.org/10.1373/clinchem.2008.115808 PMid:19406918
14. Björkman K, Jalkanen S, Salmi M, Mustonen H, Kaprio T, Kekki H, et al.A prognostic model for colorectal cancer based on CEA and a 48-multiplex serum biomarker panel. Sci Rep. 2021;11(1):4287. https://doi.org/10.1038/s41598-020-80785-1 PMid:33619304

15. Gao Y, Wang J, Zhou Y, Sheng S, Qian SY, Huo X. Evaluation of serum CEA, CA19-9, CA72-4, CA125 and ferritin as diagnostic markers and factors of clinical parameters for colorectal cancer. Sci Rep. 2018;8(1):2732. https://doi.org/10.1038/ s41598-018-21048-y PMid:29426902

16. Vogelstein B, Gillespie D. Preparative and analytical purification of DNA from agarose. Proc Natl Acad Sci USA. 1979;76(2):615-9. PMid:284385

17. Norman G. Likert scales, levels of measurement and the "laws" of statistics. Adv Health Sci Educ Theory Pract. 2010;15(5):625-32. https://doi.org/10.1007/s10459-010-9222-y PMid:20146096

18. Hajian-Tilaki K. Receiver operating characteristic (ROC) curve analysis for medical diagnostic test evaluation. Caspian J Intern Med. 2013;4(2):627-35.

PMid:24009950

19. Meng C, Yin X, Liu J, Tang K, Tang H, Liao J. TIMP-1 is a novel serum biomarker for the diagnosis of colorectal cancer: A meta-analysis. PLoS One. 2018;13(11):e0207039. https://doi. org/10.1371/journal.pone.0207039 PMid:30458003

20. Forones NM, Tanaka M. CEA and CA 19-9 as prognostic indexes in colorectal cancer. Hepatogastroenterology. 1999;46(26):905-8.

PMid:10370636

21. Vukobrat-Bijedic Z, Husic-Selimovic A, Sofic A, Bijedic N Bjelogrlic I, Gogov B, et al. Cancer antigens (CEA and CA 19-9) as markers of advanced stage of colorectal carcinoma. Med Arch. 2013;67(6):397-401. https://doi.org/10.5455/ medarh.2013.67.397-401 PMid:25568506

22. Thomsen M, Skovlund E, Sorbye H, Bolstad N, Nustad KJ Glimelius B, et al. Prognostic role of carcinoembryonic antigen and carbohydrate antigen 19-9 in metastatic colorectal cancer: A BRAF-mutant subset with high CA 19-9 level and poor outcome. $\mathrm{Br} J$ Cancer. 2018;118(12):1609-16. https://doi. org/10.1038/s41416-018-0115-9

PMid:29872151

23. Vočka M, Langer D, Fryba $V$, Petrtyl J, Hanus $T$, Kalousova M et al. Serum levels of TIMP-1 and MMP-7 as potential biomarkers in patients with metastatic colorectal cancer. Int J Biol Markers. 2019;34(3):292-301. https://doi. org/10.1177/1724600819866202

PMid:31578137

24. Kim NH, Lee MY, Park JH, Park DI, Sohn Cl, Choi K, et al Serum CEA and CA 19-9 levels are associated with the presence and severity of colorectal neoplasia. Yonsei Med J. 2017;58(5):918-24. https://doi.org/10.3349/ymj.2017.58.5.918 PMid:28792134

25. Xie L, Jiang X, Li Q, Sun Z, Quan W, Duan Y, et al. Diagnostic value of methylated Septin9 for colorectal cancer detection. Front Oncol. 2018;8:247. https://doi.org/10.3389/fonc.2018.00247 PMid:30013949

26. Alexander JC, Silverman NA, Chretien PB. Effect of age and cigarette smoking on carcinoembryonic antigen levels. JAMA. 1976;235(18):1975-9. https://doi.org/10.1001/ jama.1976.03260440027017

PMid:56468 
27. Fukuda I, Yamakado $M$, Kiyose $H$. Influence of smoking on serum carcinoembryonic antigen levels in subjects who underwent multiphasic health testing and services. J Med Syst. 1998;22(2):89-93.

PMid:9571515

28. Huang CS, Chen CY, Huang LK, Wang WS, Yang SH. Prognostic value of postoperative serum carcinoembryonic antigen levels in colorectal cancer patients who smoke. PLoS One. 2020;15(6):e0233687. https://doi.org/10.1371/journal. pone.0233687

PMid:32502149

29. Holten-Andersen MN, Christensen IJ, Nielsen HJ, Stephens RW, Jensen $\mathrm{V}$, Nielsen $\mathrm{OH}$, et al. Total levels of tissue inhibitor of metalloproteinases 1 in plasma yield high diagnostic sensitivity and specificity in patients with colon cancer. Clin Cancer Res. 2002;8(1):156-64.

PMid:11801553

30. Zhang SY, Lin M, Zhang HB. Diagnostic value of carcinoembryonic antigen and carcinoma antigen 19-9 for colorectal carcinoma. Int J Clin Exp Pathol. 2015;8(8):9404-9. PMid:26464695

31. Sun J, Zheng MY, Li YW, Zhang SW. Structure and function of Septin 9 and its role in human malignant tumors. World $\mathrm{J}$ Gastrointest Oncol. 2020;12(6):619-31. https://doi.org/10.4251/ wjgo.v12.i6.619

PMid:32699577

Author Queries???

AQ8: Kindly provide significant value 